\title{
PROBIOTIC CARRIER POTENTIAL, SENSORY PROPERTIES AND MICROBIAL QUALITY OF UGBA (Pentaclethra macrophylla) AND OGIRI (Ricinus communis)
}

\author{
ORANUSI S. *, BRAIDE W. AND CHINAKWE E. \\ Department of Microbiology, Federal University of Technology, Owerri, Imo State, Nigeria. \\ ${ }^{*}$ Corresponding Author: Email- orasoluche@yahoo.com
}

Received: August 27, 2013; Accepted: September 17, 2013

\begin{abstract}
Ugba' and 'Ogiri', fermented products of African oil bean (Pentaclethra macrophylla) and Castor oil seed (Ricinus communis), were screened for microbiological profile and ability to serve as carrier medium for probiotic, the sensory acceptability of products over twenty one days storage was also analyzed. Assay of unpasteurized products from different food vendors gave mean heterotrophic bacterial count for Ugba ranging from $6.20 \times 10^{10}-2.96 \times 10^{11} \mathrm{cfu} / \mathrm{g}$, bacteria count in Ogiri samples range from $5.10 \times 10^{10}-1.21 \times 10^{11} \mathrm{cfu} / \mathrm{g}$. Mean fungal count in Ugba samples range from $8.0 \times 10^{8}-2.01 \times 10^{10} \mathrm{cfu} / \mathrm{g}$ while count of fungi in Ogiri range from $2.1 \times 10^{9}-1.21 \times 10^{10} \mathrm{cfu} / \mathrm{g}$. The bacteria isolated include species of Bacillus, Staphylococcus, Enterococcus, Serratia, Klebsiella, Micrococcus, Pseudomonas, Streptococcus and Lactobacillus. The fungi species implicated include Rhizopus, Geotrichum, Saccharomyces, Mucor, Penicillium, Fusarium and Aspergillus. Microbial load of inoculated LAB (LASO and LAWB) multiplied in all the products throughout the storage period, there was also increase in number of recovered LAB from the stool samples through the period of study. Unpasteurized products of both Ugba and Ogiri declined in sensory attributes after day 5-9 while Ogiri and Ugba samples with LASO and LASO+LAWB combinations had better sensory properties at day 21. Ogiri and Ugba could serve as good carrier medium for probiotic with good organoleptic properties, however texture stability of these products during storage need further investigation. Hazard Analysis Critical Control Point assessment, Good Manufacturing Practice and packaging are necessary to curtail microbial contaminations in these products.
\end{abstract}

Keywords- Carrier medium, Colonization, GMP, HACCP, Intestinal mucosa, Ogiri, Sensory acceptability, Ugba, Viability.

Citation: Oranusi S., Braide W. and Chinakwe E. (2013) Probiotic Carrier Potential, Sensory Properties and Microbial Quality of Ugba (Pentaclethra macrophylla) and Ogiri (Ricinus communis). International Journal of Microbiology Research, ISSN: 0975-5276 \& E-ISSN: 09759174, Volume 5, Issue 5, pp.-476-481.

Copyright: Copyright@2013 Oranusi S., et al. This is an open-access article distributed under the terms of the Creative Commons Attribution License, which permits unrestricted use, distribution and reproduction in any medium, provided the original author and source are credited.

\section{Introduction}

The quest to find food ingredients with valuable bioactive properties has encouraged interest in lactic acid bacteria (LAB) with probiotic attributes such as antimicrobial activity against pathogenic microorganisms [1], antiviral activity [2], anti-yeast property [3], antimutagenic [4], anti-platelet aggregation and antioxidant attributes amongst others. In general, it is believed that probiotic help keep up the balance between harmful and beneficial bacteria in the gut thus maintaining a healthy digestive system [5].

The health claims of probiotic range from regulation of bowel activity and well-being to more specific actions such as, antagonistic effect on the gastroenteric pathogens like Clostridium difficile, Campylobacter jejuni, Helicobacter pylori and Rotavirus etc. [5]. Some are known to neutralize food mutagens produced in colon, shifting the immune response towards a Th2 response, alleviating allergic reactions and lowering serum cholesterol [6]. The mechanism of action of probiotic with anti-microbial properties could be due to the production of bacteriocins such as nicin or lowering the $\mathrm{pH}$ by producing acidic compounds like lactic acid, probiotic strains compete with other infectious bacteria for nutrients and cell-surface and help ward them off by inhibiting their colonization, a few strains are also known to produce active enzymes which inhibit other pathogenic bacteria [5]. The health benefits of probiotic have always been investigated with regard to their capability to sustain their availability, viability, digestibility and rendering of their health benefits to the host without altering the safety and the organoleptic properties of the food in which they have been incorporated $[5,7]$.

Today, viable probiotic strains with beneficial functional properties are available in the market as components of foods and beverages, in fermented dairy products like yogurt or as probiotic fortified foods as well as food preservatives [8]. Fermented condiments most of which are known to contain LAB give pleasant aroma to soups and sauces in many countries, especially in Africa and India where protein calorie malnutrition is a major problem [9]. They have great potential as key protein and fatty acid sources; they are good sources of gross energy and could serve as medium for food infection and intoxication. In Africa, many proteinoceous oily seeds are fermented to produce food condiments, among the fermented food condiments are Ogiri and Ugba, popular to the Igbos in the Southeastern and Yorubas in the Southwestern Nigeria $[10,11]$. To the 
Igbos these condiments add pleasant aroma to soup and they are popularly consumed as raw products without heat treatment in the preparation of African salad [12]. Based on the following analyses, the aims of this study was to investigate the presence of pathogenic microorganisms in Ogiri and Ugba, ability of Ogiri and Ugba to sustain viability of probiotic microorganisms during the shelf-life along 21 days at $28 \pm 3^{\circ} \mathrm{C}$. The organoleptic properties of the Ogiri and Ugba were also evaluated during the storage period.

\section{Materials and Methods}

\section{Sampling Sites}

The fermented Ugba and Ogiri were purchased from food vendors in different markets in three major cities in Southeastern NigeriaUmuahia in Abia state, Owerri in Imo state and Onitsha in Anambra state. The sampling markets are Isi-gate and Umuahia main markets in Umuahia. Ekeonunwa and Ihiagwa markets in Owerri and from Onitsha, Ochanja and Onitsha main markets.

\section{Sample Collection}

A total of 60 samples each of Ugba and Ogiri were purchased from the markets. Ten samples of each product were bought from a major distributor who supplies to other vendors in each of the markets. Samples were purchased from the distributors on request so as to get freshly fermented products (1-2 days) from day of manufacture according to the vendors. Samples were transported to the laboratory for analysis on day of purchase.

\section{Microbiological Analysis}

Twenty five gram $(25 \mathrm{~g})$ samples were blended in $225 \mathrm{~mL}$ sterile peptone water (10-1 dilution) sample homogenates were further serially diluted to $10^{-6}$ with the same diluents. Aliquot $0.1 \mathrm{~mL}$ volumes of each sample homogenate were inoculated by spread plate method onto Nutrient agar, MacConkey agar and Sabouraud Dextrose Agar (SDA) (all from Biomark laboratories, India), for Total Aerobic Plate Count, Coliform count and Fungal count respectively. One gram samples were inoculated into Lactose broth (Biomark laboratories, India) in capped test tubes with inverted Durham tubes for coliform test. deMann, Rogosa and Sharpe (MRS + chloramphenicol and MRS + vancomycine) agar, Manithol Salt agar(MSA), M17 agar, Salmonella-Shigella Agar-SSA (all from Biolab, Hungary) were inoculated with $0.1 \mathrm{~mL}$ of samples homogenate for isolation of Lactobacillus spp., S. aureus, Streptococci and Salmonellae. SSA was inoculated after pre-enrichment in Selenite broth (Biolab, Hungary). All culture plates were incubated aerobically at $37^{\circ} \mathrm{C}$ for $24-48 \mathrm{hrs}$. except however, SDA for fungal isolation which was incubated at laboratory room temperature $28 \pm 3^{\circ} \mathrm{C}$ for 3 to 5 days and MRS which was incubated at increased $\mathrm{CO}_{2}$ (microaerophilic) condition. At the end of incubation period, culture plates were examined for enumeration and identification of colonies.

\section{Enumeration and Characterization of Microbial Isolates}

Colony counts were with digital colony counter (Gallenkamp, England) and total population expressed as colony forming units per gram (cfug-1). Pure culture of isolates obtained by repeated subculture on freshly prepared nutrient agar was stored on slants at $4^{\circ} \mathrm{C}$ refrigeration temperature for further identification. Identification of characteristic bacteria isolates was based on colonial morphology, microscopy and biochemical tests [13] and using Biomerieux® sa API biochemical Test Kits. Fungal isolates were identified based on morphological characteristics, pigmentation on media and microscopy with reference to standard atlas and manuals [14].

\section{Coliform Test}

One gram of each sample was inoculated into sterile test tube containing Lactose broth and inverted Durham tubes. Incubation was for $24-48 \mathrm{hrs}$. at $37^{\circ} \mathrm{C}$. Tubes showing gas production and/or colour change of dye were noted as positive for Presumptive coliform test. Confirmatory coliform test was performed by streaking out positive presumptive tests on duplicate Eosin Methylene Blue (EMB) agar plates; incubation was at $37^{\circ} \mathrm{C}$ and $44^{\circ} \mathrm{C}$ for 24 hrs. respectively. Growth of characteristic colonies on EMB constitute positive confirmatory test. Colonies from EMB plates were Gram stained and inoculated into tubes containing Lactose broth with inverted Durham tubes for completed coliform test and onto Nutrient agar slants for further characterization. Inoculated tubes and slants were incubated for $24 \mathrm{hrs}$. at $37^{\circ} \mathrm{C}$. Gas production and/or colour change of dye plus Gram negative non-spore bearing rod was recorded for presence of coliform. If and when growth at $44^{\circ} \mathrm{C}$ is positive, fecal coliform is confirmed [15].

\section{Preparation of Ogiri and Ugba for Viability / Carrier Potential test and Sensory Evaluation}

For these tests, all the samples of Ugba and of Ogiri were pooled together respectively in sterile stainless-steel cooker and mixed thoroughly to avoid variability in concentration/properties thus to ensure uniformity and unbiased sampling. Three hundred gram $(0.3 \mathrm{~kg})$ of each sample was stored as negative control wrapped in sterile foils in aliquots of $25 \mathrm{~g}, 3.5 \mathrm{~g}$ and $2 \mathrm{~g}$ respectively and packaged in individual sterile plastic plates. These were labeled as unpasteurized Ogiri (UPO) and Ugba (UPU). A quantity of $1.2 \mathrm{~kg}$ of products wrapped in foil and polyethylene was heated to $80-85^{\circ} \mathrm{C}$ for $30 \mathrm{~min}$, after which it was sharply cooled to laboratory room temperature of $28^{\circ} \mathrm{C}$ in chilled water bath continuously stirred. Samples were assayed for microbial load after heating and immediately separated into four batches of $0.3 \mathrm{~kg}$ each. First batch was the positive control group without any probiotic culture and labeled pasteurized Ogiri (PO) and Ugba (PU). Second batch was homogenously mixed with $2 \mathrm{~mL}$ probiotic culture "LASO" and labeled PO + LASO and PU + LASO. To the third batch was added $2 \mathrm{~mL}$ probiotic culture "LAWB" and to the $4^{\text {th }}$ batch was added $2 \mathrm{~mL}$ mixture of LASO + LAWB probiotic cultures in equal proportions. Overnight broth cultures of LASO and LAWB were standardized to $1.5 \times 10^{8}$ cells using 0.5 McFarland standards before mixing with products. The four batches were packaged as in negative control. Storage of all samples was at room temperature $28 \pm 3^{\circ} \mathrm{C}$. Ogiri and Ugba are traditionally preserved at room temperature thus the choice of this storage condition.

\section{Viability Test}

Viabilities of LASO and LAWB were monitored during the storage period $(1,5,9,13,17,21$. days) for Ogiri and Ugba PO + LASO, $P O+L A W B, P O+L A S O+L A W B$ and PU + LASO, PU + LAWB, $P U+L A S O+L A W B$. Populations of the contaminants microfloras were also evaluated for all samples studied (controls and test sample mixes). At each sampling day, portions of $25 \mathrm{~g}$ were collected aseptically and homogenized with $225 \mathrm{~mL}$ of sterile peptone water. Further serial dilutions to $10^{6}$ were carried out with the same diluents. Nutrient agar, MacConkey agar, SDA, MRS, MSA, M17 agar, Salmonella-Shigella Agar- SSA were inoculated with $0.1 \mathrm{~mL}$ of samples homogenate as earlier stated for Total Aerobic Plate Count, Coliform count, Fungal count, isolation of Lactobacillus spp., S. aureus, Streptococci and Salmonellae respectively. 


\section{Test for Colonization and Attachment to Intestinal Mucosa}

The method as described by Oranusi, et al [16] was adopted with slight modification. Twenty healthy volunteers divided into two groups ( $A$ and $B$ ) of ten, participated in this exercise. Group A assayed for Ogiri, while group B was for Ugba. The groups were further sub divided into five subgroups of two volunteers assigned to the different products. Subjects were administered $3.5 \mathrm{~g}$ (approximate weight of common menthols / confectionaries in Nigerian markets) of the product on each day of evaluation $(1,5,9,13$, 17, 21 days). Subjects abstained from consumption of any fermented products; milk products / probiotic for a week after, which fecal samples were screened for presence of test organisms / LAB prior to products administration and were to abstain from consumption of any other fermented products, milk products/probiotic during this period. On each evaluation day prior to product administration and two weeks post 21 days storage, stool samples from subjects were analyzed for test organisms. Microbiological analysis of fecal samples was performed by plating sample on MRS + Chloramphenicol and MRS + vancomycine) agar medium. Isolates were enumerated and recorded. In addition, further biochemical tests [13] and using Biomerieux ${ }^{\circledR}$ sa API biochemical Test Kits were carried out to confirm the isolates as organisms of interest.

\section{Physico-Chemical Analysis}

The moisture content was determined by drying $2 \mathrm{~g}$ sample at 100 $105^{\circ} \mathrm{C}$ to constant weight [17]. The $\mathrm{pH}$ of the samples was determined on each sampling day using $\mathrm{pH}$ meter ( $\mathrm{pH} 211$ microprocessor, Hanna instruments).

\section{Sensory Evaluation}

Panelists consist of vendors, producers and individuals that eat Ogiri / Ugba rich food / meal at least 2-5 times a week. Twenty (20) panelists were used to evaluate the Ogiri / Ugba for organoleptic characteristics aroma/flavor, color, texture and taste. A grading scale of $5=$ very good; $4=$ good; $3=$ fair; $2=$ poor; $1=$ very poor was used to compare control samples UPO, UPU, PO and PU with test samples PO + LASO, PO + LAWB, PO + LASO + LAWB, PU + LASO, PU + LAWB and PU + LASO + LAWB. The results were subjected to statistical analysis.

\section{Statistical Analysis}

The statistical analysis of the microbial loads and sensory characteristics was done using SPSS 20.0 software for windows [18] and employing One-way ANOVA at 0.01 level of significance. Further test on level of significant was carried out using Duncan Multiple Range tests (DMRT) [19].

\section{Results}

[Table-1] shows the mean microbial load of samples before and after heat treatment prior to storage test. Heating significantly re- duced the TAPC and eliminated the contaminant coliform, fungal and $L A B$ populations. The diverse population of the contaminants mainly of bacillus spp., moulds and yeasts are shown in [Table-2]. The table also reveals the presence of coliforms in both samples. [Table-3] presents the mean microbial load cfug-1 of Ogiri and Ugba during storage. There was increase in microbial load down the storage period, however, the control samples had decline at day 21. The viability of LASO and LAWB and their combinations LASO + LAWB during storage is shown in [Table-4]. The mean count of LASO and LASO + LAWB increased from $10^{8}$ to $10^{9}$. LAWB population was maintained at $10^{8}$ throughout the storage period. Similarly the recovery of LASO and LAWB from stool sample showed an increase in recovery rate through the storage period, LASO and LASO + LAWB increased to $10^{6}-10^{7}$ at days 13-21 before decline at day 35. Maximum LAWB recovery was $10^{5}$ with a decline also at day 35 . The sensory characteristics of Ogiri and Ugba during storage are shown in [Table-5]. The table shows that at days 9 (Ugba) and 13(Ogiri) the unpasteurized products are fairly acceptable, however, the pasteurized samples lasted to day 13 (Ugba) and day 17(Ogiri). LASO and LAWB treated samples were fairly acceptable at day 17 and 21. Texture was the most affected of the properties and deteriorated in all Ugba samples from day 9. The Aroma / Flavour shows to be the next affected after texture. [Fig-1] and [Fig-2] presents the $\mathrm{pH}$ values of the products. It reveals that heating the products controlled the fluctuation in $\mathrm{pH}$ of the unpasteurized samples UPU and UPO. Drop in $\mathrm{pH}$ of products tend to follow the order sample + LASO > sample + LASO + LAWB > sample + LAWB > unpasteurized samples $>$ pasteurized samples. Moisture contents of Ugba and Ogiri range from $64.5 \pm 0.3-65.2 \pm 0.2$ and $55.8 \pm 0.2$ $56.2 \pm 0.1 \%$ during the storage period.

Table 1- Mean microbial load cfug-1 of Ogiri and Ugba before and after heat treatment

\begin{tabular}{lcccc|} 
Microbial Count & \multicolumn{2}{c}{ Ugba } & \multicolumn{2}{c}{ Ogiri } \\
& Before Heating & After Heating & Before Heating & After Heating \\
\hline TAPC & $2.34 \times 10^{11}$ & $9.8 \times 10^{1}$ & $4.32 \times 10^{10}$ & $6.6 \times 10^{1}$ \\
Coliform count & $1.98 \times 10^{5}$ & - & $9.38 \times 10^{4}$ & - \\
Fungal count & $1.96 \times 10^{6}$ & $<10$ & $9.27 \times 10^{5}$ & - \\
LAB count & $3.70 \times 10^{6}$ & - & $7.91 \times 10^{4}$ & - \\
\hline
\end{tabular}

Table. 2- Microorganisms isolated from Ogiri and Ugba

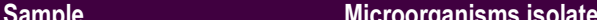

B. megaterium, Staphylococcus epidermides, E. coli, Proteus spp, Alcaligenes spp, B. licheniformis, Pseudomonas spp, Micrococcus spp., Staphy-

Ogiri lococcus aureus, B. subtilis, Leuconostoc spp, Lactobacillus spp, Mucor spp, Saccharomyces cerevisiae, Fusarium spp, Penicillium spp, Rhizopus spp, Aspergillus spp.

B. circulans, Leuconostoc spp, Staphylococcus aureus, Micrococcus spp, B. licheniformis, Lactobacillus plantarum, Streptococcus spp, Proteus spp Enterobacter spp, B. megaterium, E. coli, Candida spp, Geotrichum spp, Klebsiella spp, B. macerans, Lactobacillus spp, Serratia spp, B. subtilis, Saccharomyces spp, Aspergillus niger, Mucor spp, Penicillium spp, Fusarium spp, Corynebacterium spp.

Table 3- Mean microbial load cfug-1 of Ogiri and Ugba during storage

\begin{tabular}{|c|c|c|c|c|c|c|c|c|c|c|}
\hline Storage Time (Day) & UPU & PU & PU + LASO & PU + LAWB & PU + LASO + LAWB & UPO & PO & PO+ LASO & PO + LAWB & $P O+L A S O$ + LAWB \\
\hline 1 & $2.3 \times 10^{11}$ & $9.8 \times 10^{1}$ & $1.5 \times 10^{8}$ & $1.5 \times 10^{8}$ & $1.5 \times 10^{8}$ & $4.3 \times 10^{10}$ & $6.6 \times 10^{1}$ & $1.5 \times 10^{8}$ & $1.5 \times 10^{8}$ & $1.5 \times 10^{8}$ \\
\hline 5 & $4.2 \times 10^{11}$ & $1.3 \times 10^{1}$ & $2.6 \times 10^{8}$ & $1.3 \times 10^{8}$ & $1.6 \times 10^{7}$ & $5.2 \times 10^{11}$ & $7.2 \times 10^{1}$ & $1.2 \times 10^{6}$ & $7.0 \times 10^{6}$ & $1.3 \times 10^{8}$ \\
\hline 9 & $1.3 \times 10^{12}$ & $5.6 \times 10^{2}$ & $6.6 \times 10^{9}$ & $4.0 \times 10^{7}$ & $1.6 \times 10^{8}$ & $3.2 \times 10^{12}$ & $2.5 \times 10^{2}$ & $3.4 \times 10^{7}$ & $2.3 \times 10^{6}$ & $2.8 \times 10^{8}$ \\
\hline 13 & $5.8 \times 10^{12}$ & $2.0 \times 10^{3}$ & $4.3 \times 10^{9}$ & $8.0 \times 10^{7}$ & $4.5 \times 10^{8}$ & $6.1 \times 10^{12}$ & $6.3 \times 10^{2}$ & $5.6 \times 10^{9}$ & $1.5 \times 10^{7}$ & $6.8 \times 10^{8}$ \\
\hline 17 & $8.2 \times 10^{12}$ & $3.1 \times 10^{3}$ & $7.5 \times 10^{9}$ & $1.0 \times 10^{8}$ & $2.1 \times 10^{9}$ & $4.5 \times 10^{12}$ & $3.8 \times 10^{3}$ & $1.3 \times 10^{9}$ & $4.1 \times 10^{8}$ & $3.1 \times 10^{9}$ \\
\hline 21 & $1.1 \times 10^{11}$ & $2.4 \times 10^{3}$ & $8.0 \times 10^{9}$ & $2.8 \times 10^{8}$ & $2.3 \times 10^{9}$ & $7.3 \times 10^{10}$ & $3,6 \times 10^{4}$ & $6.4 \times 10^{9}$ & $8.3 \times 10^{8}$ & $8.2 \times 10^{9}$ \\
\hline
\end{tabular}


Table 4- Mean count (cfug-1) of $L A B$ recovered from stool samples

\begin{tabular}{|lcccccccccc|} 
Storage Time (Day) & UPU & PU & PU + LASO & PU + LAWB & PU + LASO + LAWB & UPO & PO & PO+ LASO & PO + LAWB & PO + LASO + LAWB \\
\hline $1^{*}$ & - & - & - & - & - & - & - & - & - & - \\
5 & - & - & $1.0 \times 10^{2}$ & $1.4 \times 10^{1}$ & $3.0 \times 10^{2}$ & - & - & $1.2 \times 10^{3}$ & $2.3 \times 10^{2}$ & $1.4 \times 10^{2}$ \\
9 & $<10$ & - & $1.6 \times 10^{4}$ & $3.3 \times 10^{2}$ & $3.9 \times 10^{4}$ & - & - & $2.1 \times 10^{4}$ & $1.8 \times 10^{3}$ & $3.5 \times 10^{3}$ \\
13 & $1.1 \times 10^{1}$ & - & $2.1 \times 10^{6}$ & $1.8 \times 10^{4}$ & $1.3 \times 10^{6}$ & $<10$ & - & $2.4 \times 10^{6}$ & $1.2 \times 10^{5}$ & $4.2 \times 10^{6}$ \\
17 & $1.1 \times 10^{1}$ & - & $4.1 \times 10^{6}$ & $3.2 \times 10^{5}$ & $2.2 \times 10^{6}$ & $<10$ & - & $3.5 \times 10^{6}$ & $2.5 \times 10^{5}$ & $3.4 \times 10^{6}$ \\
21 & $<10$ & - & $4.8 \times 10^{6}$ & $3.5 \times 10^{5}$ & $8.2 \times 10^{7}$ & - & - & $4.6 \times 10^{7}$ & $5.6 \times 10^{5}$ & $5.1 \times 10^{6}$ \\
$35^{* *}$ & - & - & $3.7 \times 10^{3}$ & $7.8 \times 10^{2}$ & $6.1 \times 10^{4}$ & - & - & $1.1 \times 10^{5}$ & $2.8 \times 10^{3}$ & $3.3 \times 10^{5}$ \\
\hline
\end{tabular}

${ }^{*}=L A B$ recovery from subjects in each category before sample administration

${ }^{* *}=L A B$ recovery from subjects in each category 2 weeks after sample administration

Table 5- Sensory evaluation of Ogiri and Ugba during storage

\begin{tabular}{|c|c|c|c|c|c|c|c|c|c|c|c|}
\hline Day & Characteristics & UPU & PU & PU + LASO & PU + LAWB & PU + LASO + LAWB & UPO & PO & PO+ LASO & PO + LAWB & PO + LASO + LAWB \\
\hline \multirow{5}{*}{1} & Aroma/Flavour & $5.0 \pm 0.1 \mathrm{ax}$ & $4.5 \pm 0.3^{\text {by }}$ & $4.6 \pm 0.2^{\mathrm{bz}}$ & $4.5 \pm 0.4^{\mathrm{bx}}$ & $4.9 \pm 0.2^{\text {ay }}$ & $4.9 \pm 0.3 \mathrm{ax}$ & $4.6 \pm 03^{\text {by }}$ & $4.8 \pm 02^{\text {at }}$ & $4.6 \pm 04^{\mathrm{bx}}$ & $4.9 \pm 02^{\text {ay }}$ \\
\hline & Colour & $4.9 \pm 0.2^{\mathrm{ax}}$ & $4.1 \pm 0.2^{\text {by }}$ & $4.7 \pm 0.5^{\mathrm{ct}}$ & $4.2 \pm 0.3^{b x}$ & $4.8 \pm 0.3 \mathrm{acz}$ & $4.8 \pm 0.2^{\mathrm{ax}}$ & $4.8 \pm 0.3 \mathrm{az}$ & $4.8 \pm 0.5^{\text {at }}$ & $4.8 \pm 0.2^{\mathrm{ay}}$ & $4.8 \pm 02^{a z}$ \\
\hline & Taste & $4.7 \pm 0.6^{\mathrm{ax}}$ & $4.2 \pm 0.5$ by & $4.6 \pm 0.4$ acy & $4.2 \pm 0.4 \mathrm{bx}$ & $4.8 \pm 0.2^{\mathrm{az}}$ & $4.8 \pm 0.3$ ax & $4.5 \pm 0.2^{b z}$ & $4.6 \pm 0.2^{\mathrm{bcy}}$ & $4.5 \pm 0.3^{\text {by }}$ & $4.7 \pm 0.3 \mathrm{acz}$ \\
\hline & Texture & $4.8 \pm 0.4 \mathrm{ax}$ & $4.0 \pm 0.4 \mathrm{bz}$ & $4.5 \pm 0.3 c y$ & $4.0 \pm 0.5^{b z}$ & $4.8 \pm 0.3$ at & $4.6 \pm 0.4^{\text {by }}$ & $4.8 \pm 0.3 \mathrm{ax}$ & $4.8 \pm 0.4 \mathrm{ax}$ & $4.7 \pm 0.4$ aby & $4.8 \pm 0.2^{\text {at }}$ \\
\hline & Aroma/Flavour & $4.9 \pm 0.3$ ay & $4.4 \pm 0.4^{b x}$ & $4.5 \pm 0.4^{\mathrm{bz}}$ & $4.4 \pm 0.3^{\text {by }}$ & $4.8 \pm 0.4^{\text {ay }}$ & $4.8 \pm 0.6^{\text {ay }}$ & $4.6 \pm 0.4^{\mathrm{bt}}$ & $4.8 \pm 0.4 \mathrm{az}$ & $4.6 \pm 0.3^{b x}$ & $4.8 \pm 0.3^{\text {ay }}$ \\
\hline \multirow{4}{*}{5} & Colour & $4.9 \pm 0.2^{\mathrm{az}}$ & $4.1 \pm 0.3^{b x}$ & $4.6 \pm 0.4 \mathrm{cy}$ & $4.1 \pm 0.4^{\text {by }}$ & $4.6 \pm 0.3^{c z}$ & $4.8 \pm 0.4^{\mathrm{az}}$ & $4.8 \pm 0.2^{\mathrm{ay}}$ & $4.8 \pm 0.3 \mathrm{ax}$ & $4.8 \pm 0.4^{\mathrm{az}}$ & $4.8 \pm 0.3^{\text {at }}$ \\
\hline & Taste & $4.7 \pm 0.5$ ay & $4.0 \pm 0.4 \mathrm{bx}$ & $4.4 \pm 0.5 c y$ & $3.9 \pm 0.4 \mathrm{bz}$ & $4.8 \pm 0.4^{\text {at }}$ & $4.7 \pm 0.1$ ay & $4.6 \pm 0.4$ aby & $4.7 \pm 0.2^{\mathrm{az}}$ & $4.5 \pm 0.5 \mathrm{bx}$ & $4.7 \pm 0.2$ at \\
\hline & Texture & $4.8 \pm 0.3^{\text {at }}$ & $4.0 \pm 0.2^{b x}$ & $4.0 \pm 0.3^{\text {by }}$ & $4.0 \pm 0.3^{b t}$ & $4.0 \pm 0.3^{\text {by }}$ & $4.7 \pm 0.3^{\text {at }}$ & $4.8 \pm 0.2^{\mathrm{ax}}$ & $4.8 \pm 0.2^{\mathrm{az}}$ & $4.7 \pm 0.3^{\text {ay }}$ & $4.8 \pm 04 a z$ \\
\hline & Aroma/Flavour & $3.0 \pm 0.4 \mathrm{ax}$ & $4.0 \pm 0.3^{\text {by }}$ & $4.6 \pm 0.5^{\mathrm{ct}}$ & $4.5 \pm 0.4$ cy & $4.8 \pm 0.2 \mathrm{dx}$ & $4.0 \pm 0.3$ ay & $4.7 \pm 0.4 \mathrm{bz}$ & $4.8 \pm 0.4 \mathrm{ax}$ & $4.7 \pm 0.3^{\mathrm{bz}}$ & $4.8 \pm 0.2^{b x}$ \\
\hline \multirow{4}{*}{9} & Colour & $3.0 \pm 0.5 \mathrm{ax}$ & $4.2 \pm 0.4^{\mathrm{bz}}$ & $4.6 \pm 0.3^{\mathrm{ct}}$ & $4.3 \pm 0.1 \mathrm{bz}$ & $4.7 \pm 0.3^{c x}$ & $4.2 \pm 0.4^{\text {ay }}$ & $4.5 \pm 0.3^{\text {by }}$ & $4.8 \pm 0.2^{c x}$ & $4.7 \pm 0.2^{\mathrm{cy}}$ & $4.8 \pm 0.10 x$ \\
\hline & Taste & $3.0 \pm 0.6$ ay & $4.0 \pm 0.3^{b x}$ & $4.3 \pm 0.4^{c y}$ & $4.1 \pm 0.3^{\mathrm{bz}}$ & $4.4 \pm 0.1 \mathrm{ct}$ & $4.0 \pm 0.5^{\mathrm{ax}}$ & $4.7 \pm 0.2^{\mathrm{bz}}$ & $4.7 \pm 0.2 \mathrm{bx}$ & $4.8 \pm 0.3^{\text {by }}$ & $4.8 \pm 0.2^{\mathrm{bt}}$ \\
\hline & Texture & $3.0 \pm 0.3^{a z}$ & $3.0 \pm 0.2^{\text {ay }}$ & $3.1 \pm 0.5^{\mathrm{ax}}$ & $3.0 \pm 0.4^{\text {at }}$ & $3.0 \pm 0.4^{\mathrm{az}}$ & $4.2 \pm 0.5^{\text {ay }}$ & $4.2 \pm 0.1 \mathrm{ax}$ & $4.3 \pm 0.2^{\mathrm{az}}$ & $4.2 \pm 0.4$ ay & $4.3 \pm 0.2^{\mathrm{ax}}$ \\
\hline & Aroma/Flavour & $2.5 \pm 0.6^{\mathrm{ax}}$ & $3.5 \pm 0.4$ by & $4.5 \pm 0.1 \mathrm{cz}$ & $4.0 \pm 0.2^{\mathrm{dt}}$ & $4.5 \pm 0.3^{c x}$ & $3.7 \pm 0.1^{\text {ay }}$ & $4.5 \pm 0.2^{\mathrm{bx}}$ & $4.8 \pm 0.4 \mathrm{ct}$ & $4.4 \pm 0.1 \mathrm{bz}$ & $4.8 \pm 0.1^{\mathrm{ct}}$ \\
\hline \multirow{4}{*}{13} & Colour & $2.2 \pm 0.1$ ay & $4.0 \pm 0.5^{b x}$ & $4.4 \pm 0.5^{c z}$ & $4.2 \pm 0.6^{\mathrm{bx}}$ & $4.0 \pm 0.3$ ay & $3.5 \pm 0.6^{\mathrm{ax}}$ & $4.5 \pm 0.2^{\mathrm{bz}}$ & $4.8 \pm 0.3^{\text {by }}$ & $4.5 \pm 0.3^{\text {bt }}$ & $4.6 \pm 0.2^{b z}$ \\
\hline & Taste & $2.5 \pm 0.4 \mathrm{ax}$ & $3.6 \pm 0.3^{\text {by }}$ & $4.4 \pm 0.3 \mathrm{cz}$ & $4.0 \pm 0.2^{\mathrm{dx}}$ & $4.0 \pm 0.1 \mathrm{dy}$ & $3.0 \pm 0.6^{\text {by }}$ & $4.5 \pm 0.2^{\mathrm{az}}$ & $4.6 \pm 0.2^{\mathrm{bt}}$ & $4.2 \pm 0.2 \mathrm{cy}$ & $4.6 \pm 0.3 \mathrm{az}$ \\
\hline & Texture & $2.8 \pm 0.5^{\text {at }}$ & $2.6 \pm 0.4^{b x}$ & $2.7 \pm 0.2^{\mathrm{abz}}$ & $2.5 \pm 0.5^{\text {bcy }}$ & $2.6 \pm 0.2^{\mathrm{bz}}$ & $3.5 \pm 0.2^{\mathrm{az}}$ & $4.0 \pm 0.3^{b y}$ & $4.0 \pm 0.3^{\text {by }}$ & $4.2 \pm 0.1^{\mathrm{bt}}$ & $3.8 \pm 0.10 x$ \\
\hline & Aroma/Flavour & $2.0 \pm 0.4 \mathrm{ax}$ & $3.0 \pm 0.1$ by & $4.0 \pm 0.2 \mathrm{cz}$ & $3.8 \pm 0.2^{\mathrm{dt}}$ & $4.1 \pm 0.5^{c x}$ & $2.7 \pm 0.3$ ay & $3.5 \pm 0.5^{b x}$ & $4.0 \pm 0.2^{\mathrm{cz}}$ & $3.5 \pm 0.2^{b x}$ & $4.2 \pm 0.3 c x$ \\
\hline \multirow{4}{*}{17} & Colour & $2.0 \pm 0.3$ ay & $3.5 \pm 0.3^{\mathrm{bz}}$ & $4.0 \pm 0.4 \mathrm{cx}$ & $4.0 \pm 0.4^{\mathrm{ct}}$ & $4.0 \pm 0.2^{\mathrm{cz}}$ & $2.8 \pm 0.2^{\mathrm{ax}}$ & $4.0 \pm 0.2^{\text {by }}$ & $4.0 \pm 0.3 \mathrm{bx}$ & $4.0 \pm 0.3^{\mathrm{bz}}$ & $4.0 \pm 0.2^{\mathrm{bz}}$ \\
\hline & Taste & $2.0 \pm 0.2$ ay & $3.0 \pm 0.2^{\mathrm{bt}}$ & $4.0 \pm 0.3^{c x}$ & $3.8 \pm 0.3^{c y}$ & $3.0 \pm 0.3^{\mathrm{bz}}$ & $2.5 \pm 0.3 \mathrm{ax}$ & $3.5 \pm 0.3^{\text {by }}$ & $4.0 \pm 0.4 c y$ & $3.5 \pm 0.1 \mathrm{bx}$ & $4.0 \pm 0.2^{c y}$ \\
\hline & Texture & $2.0 \pm 0.2 \mathrm{ax}$ & $2.0 \pm 0.1$ ay & $2.3 \pm 0.3^{b t}$ & $2.1 \pm 0.2^{b z}$ & $2.0 \pm 0.2^{\mathrm{ax}}$ & $3.0 \pm 0.5$ ay & $3.1 \pm 0.3 \mathrm{abz}$ & $3.1 \pm 0.1 \mathrm{abx}$ & $3.2 \pm 0.2$ by & $3.0 \pm 0.4 \mathrm{az}$ \\
\hline & Aroma/Flavour & $1.3 \pm 0.1 \mathrm{az}$ & $2.2 \pm 0.5$ by & $3.5 \pm 0.3^{\mathrm{ct}}$ & $3.0 \pm 0.4 \mathrm{dz}$ & $3.6 \pm 0.3^{c x}$ & $2.1 \pm 0.4^{\mathrm{ax}}$ & $3.0 \pm 0.2^{\mathrm{bt}}$ & $3.6 \pm 0.2^{\mathrm{ct}}$ & $3.2 \pm 0.3^{b t}$ & $3.6 \pm 0.3 c x$ \\
\hline \multirow{3}{*}{21} & Colour & $1.2 \pm 0.3$ ay & $2.3 \pm 0.3^{b t}$ & $3.0 \pm 0.4 \mathrm{cy}$ & $3.2 \pm 0.3 \mathrm{cx}$ & $3.0 \pm 0.1 \mathrm{cz}$ & $2.1 \pm 0.2^{\mathrm{az}}$ & $2.4 \pm 0.4 \mathrm{bt}$ & $3.0 \pm 0.4 c y$ & $3.1 \pm 0.1 \mathrm{cx}$ & $3.5 \pm 0.2^{\mathrm{dx}}$ \\
\hline & Taste & $1.2 \pm 0.3 \mathrm{ax}$ & $2.0 \pm 0.2$ by & $3.0 \pm 0.4 c z$ & $3.0 \pm 0.4 \mathrm{ct}$ & $2.8 \pm 0.3^{\mathrm{dy}}$ & $2.0 \pm 0.5^{\text {ay }}$ & $3.0 \pm 0.2^{\mathrm{az}}$ & $3.4 \pm 0.2^{\mathrm{bx}}$ & $2.3 \pm 0.3 \mathrm{ct}$ & $3.5 \pm 0.5 \mathrm{bz}$ \\
\hline & Texture & $1.0 \pm 0.2$ ay & $1.0 \pm 0.4^{\mathrm{ax}}$ & $1.2 \pm 0.2^{\mathrm{az}}$ & $1.0 \pm 0.4^{\mathrm{at}}$ & $1.1 \pm 0.2^{\text {ay }}$ & $2.5 \pm 0.6^{\mathrm{az}}$ & $2.8 \pm 0.1^{\text {by }}$ & $2.5 \pm 0.3^{\text {ay }}$ & $2.0 \pm 0.2^{\mathrm{ct}}$ & $2.5 \pm 0.2^{\mathrm{az}}$ \\
\hline
\end{tabular}

abcd: Values in same row with same superscript for same product (ugba to ugba/ogiri to ogiri) are not significantly different ( $p<0.01)$.

txyz: Values in same row with same superscript for different product (ugba to ogiri) but same treatment are not significantly different ( $p<0.01$ ). upu: unpasteurized ugba; pu: pasteurized ugba; LASO: lactic acid bacteria 'SO'; LAWB: lactic acid bacteria 'WB'; upo: unpasteurized ogiri; po: pasteurized ogiri

Grading scale: 5= very good; 4= good; 3= fair; 2= poor; 1= very poor

\section{Discussion}

The heating of samples and reduction in the microbial load prior to storage could have been responsible for eliminating the fluctuations in the $\mathrm{pH}$ of UPO and UPU and thus creating the stabilizing effect in $\mathrm{PO}$ and PU. This allows for the specific $\mathrm{pH}$ activities of LASO and LAWB. Heat is known to affect $\mathrm{pH}$ due to the dissociation of $\mathrm{H}^{+}$as temperature increases [20].

The diverse microbial population of Ugba and Ogiri point to the fact that these are products of mixed microbial fermentation and the local technology employed in their production and packaging still need to be optimized by use of starter cultures, good manufacturing practice, effective HACCP and good packaging to eliminate or reduce the microbial contamination in these products. Mixed microbial populations have also been reported in these products [21-24]. The presence of bacillus spp. as major contaminants is in agreement with the reports of Ejiofor, et al [10], Sergius, et al [21] and Odunfa [25]. The fermentation of Ugba and Ogiri has been reported to be associated with proteolytic bacillus spp., B. subtilis, B. licheniformis, $B$. megaterium, $B$. macerans and $B$. circulans $[21,26,27]$. The presence of $B$. cereus in these products, however, calls for concern because $B$ cereus is implicated in food borne diseases. $S$. aureus and other staphylococcus spp. identified is common human flora and environmental contaminants, their presence could therefore be from the producers, utensils and environment. Some strains of $S$. aureus are toxigenic and have been associated to food borne intoxication $[28,29]$, their presence therefore call for concern. The presence of coliforms is an indication of poor sanitary condition in the production of Ugba and Ogiri. Poor water quality and compromise in hygiene standard during production could be a source of coliform to these products. 
Fungi are common place as environmental contaminants, due to the ability of moulds to produce spores. Fungal spp. and LABs have always been associated with mixed/ unregulated fermentations. The presence of mycotoxigenic strains of fungal spp. could be dangerous if and when deleterious mycotoxins are produced [30-32]. Species of Aspergillus, Penicillium, Fusarium are known to produce potent mycotoxins, their presence in food must not therefore be treated with levity. In uncontrolled fermentation such as the traditional production of Ugba and Ogiri, fermentation failure could occur, thus the safety of these uncontrolled products cannot be guaranteed.

The increase in microbial load of LASO and LAWB during the storage period and its concomitant increase in stool recoveries indicate that Ugba and Ogiri effectively supported the growth of $L A B$ and the organisms were established/ attached and colonized the intestinal mucosa, LASO and LASO + LAWB combination, however gave a better result compared to other samples. The burden of LASO and LASO + LAWB combination to level of $10^{6}$ in stool and the multiplication to levels of $10^{8}-10^{9}$ in Ugba and Ogiri shows that these organisms could be transported via the medium of Ugba and Ogiri to deliver probiotic properties. Probiotic microorganisms in level of $10^{6}$ cfu $\mathrm{g}^{-1}$ of food at the time of consumption have been recommended as level to provide beneficial effects for consumers [33]. Several research findings have documented the probiotic carrier potential of both fermented and none fermented products [16,34-37].

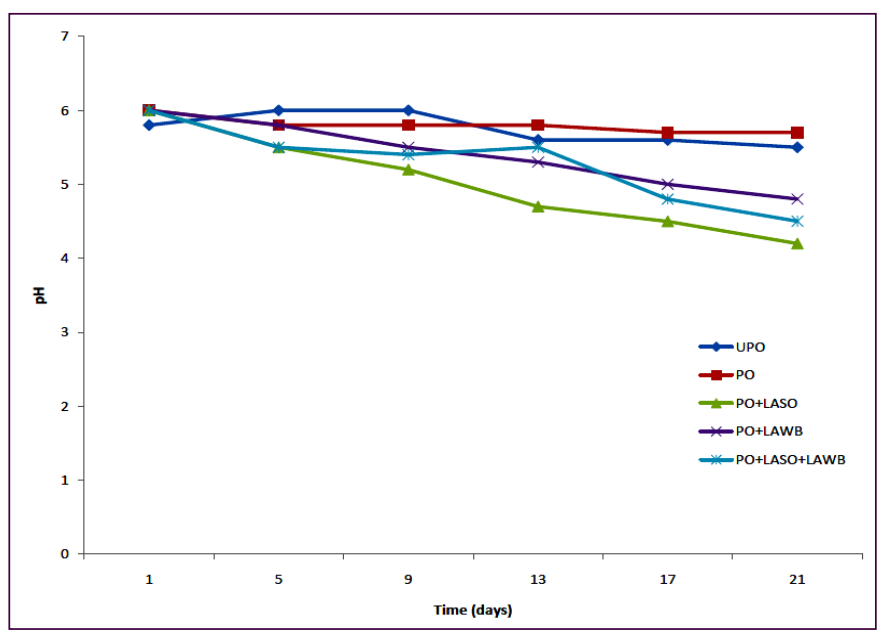

Fig. 1- Change in $\mathrm{pH}$ of Ogiri during storage

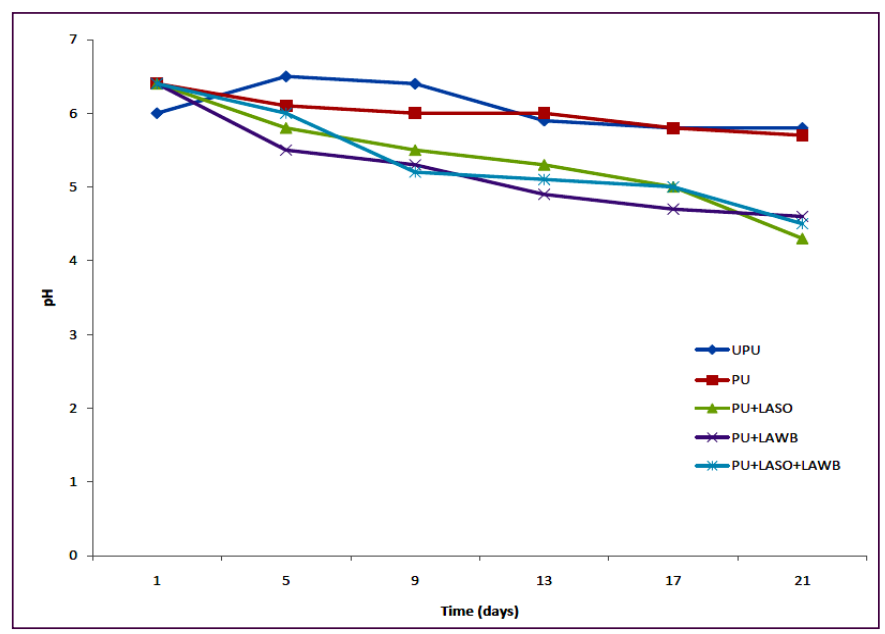

Fig. 2- Change in $\mathrm{pH}$ of Ugba during storage
The sensory evaluation scores shows that the best products are in the order $\mathrm{PO}+\mathrm{LASO}>\mathrm{PO}+\mathrm{LASO}+\mathrm{LAWB}>\mathrm{PO}+\mathrm{LAWB}>\mathrm{PU}+$ $\mathrm{LASO}>\mathrm{PU}+\mathrm{LASO}+\mathrm{LAWB}>\mathrm{PU}+\mathrm{LAWB}$. This trend is equally reflected in [Fig-1] and [Fig-2] considering the $\mathrm{pH}$ drop necessary to preserve these products.

The sensory property of probiotic in Strawberry ice cream was observed with respect to its acidity to be of better flavour and taste at $\mathrm{pH}$ of 5.6 [38]. The proliferation of LASO in the products and its higher recovery rate in stool samples specifically in Ogiri feed subjects, point to the fact that LASO is better attached to the intestinal mucosa and Ogiri is a better carrier medium. This report is in tandem with the findings of Ranadheera, et al [39]; they observed that different types of food products influence differently the growth and viability of probiotic. Similarly, Majchrzak, et al [40] noted that there are sensory differences in probiotic in different medium. The sensorial scores of the pasteurized probiotics treated groups were higher than the unpasteurized samples. Significant changes $(P<0.01)$ were observed throughout the 21 days storage period in all the Ogiri and Ugba samples.

\section{Conclusion}

This study has shown that Ogiri and Ugba sold in the markets has high microbial load above $10^{6}$ tolerable limits of contaminants in food [41]. Heating/ pasteurization reduced the load to acceptable limit. Ogiri and Ugba were shown to be good carrier medium for the incorporation of probiotic (LASO and LAWB) during 21 days storage. Pasteurization of Ogiri and Ugba preserved their sensory properties beyond 3-7 days keeping quality of these products under room temperature storage [42]. Although the texture of Ugba scored low in the heat treated samples, other sensory attributes of Ugba and Ogiri were fairly acceptable even at 21 day. The attachment and colonization attributes of LASO was better than LAWB signifying that LAWB may not be a suitable candidate for direct incorporation into Ugba and Ogiri. Similarly the viability of probiotic in Ogiri is better than in Ugba indicating that Ogiri is a good carrier medium. Further study on the texture stability of Ugba and of Ogiri is necessary. The carrier potential of Ogiri and Ugba to other probiotic organisms demands further investigation.

\section{Acknowledgement}

Authors acknowledge the management of Leuwenhoek laboratory, Nekede, Imo state, Nigeria for graciously providing the probiotic, part funding and all the technical support for this work.

Conflict of Interest: None declared.

\section{References}

[1] Hugo A.A, Antoni G.L. and De P.P.F. (2006) Int. J. Food Microb., 111, 191-196.

[2] Botic T.A. (2007) Int. J. Food Microbiol., 115, 227-234.

[3] Kantachote D. (2008) International Conference of Food Microbiology, 33-38.

[4] Lim Sung-Mee L.S.M., Lee Goon-Ja L.G.J., Park Sun-Mee P.S.M., Ahn Dong-Hyun A.D.H. and Im Dong-Soon I.D.S. (2006) Food Science and Biotechnology, 15(5), 792-798.

[5] Sleator R.D. (2010) Discovery Medicine, 51, 119-124.

[6] Tannock G. (2005) Probiotics and Prebiotics: Scientific Aspects, 1st ed., Caister Academic Press, Wymondham, UK.

[7] Lian W.C., Hsiao H.C. and Chou C.C. (2003) International Jour- 
nal of Food Microbiology, 86(3), 293-301.

[8] Soomro A.H., Masud T. and Anwaar K. (2002) Pakistan Journal of Nutrition, 1(1), 20-24.

[9] Sarkar P.K., Cook P.E. and Owens J.D. (1993) World Journal of Microbiology and Biotechnology, 9(3), 295-299.

[10]Ejiofor M.A.N., Oti E. and Okafor J.C. (1987) International Tree Crops Journal, 4(2-3), 135-144.

[11]Ogunshe A.A.O., Ayodele A.I. and Okonko I.O. (2006) Pakistan Journal of Nutrition, 5(1), 51-58.

[12]Oranusi S., Braide W., Eze U.C. and Chinakwe E. (2013) Journal of Emerging Trends in Engineering and Applied Sciences, 4 (2), 287-292.

[13]Jolt J.G., Krieg N.R., Sneath P.H.A., Stanley J.T. and Williams S.T. (1994) Bergey's Manual of Systematic Bacteriology, 9th ed., Williams \& Wilkins Co. Baltimore, Maryland, 786.

[14]Tsuneo W. (2010) Pictorial atlas of soil and seed fungi: Morphologies of cultural fungi and Key to Species, 3rd ed.

[15]Oranusi S., Onyeike E., Galadima M. and Umoh V.J. (2004) Nigerian Journal of Microbiology, 18(1-2), 346- 362.

[16]Oranusi S., Madu S.A., Braide W. and Oguoma O.I. (2011) Journal of Microbiology and Antimicrobials, 3(6), 146-152.

[17]AOAC (1990) Official Method of Analysis, 13th ed., The Association of Analytical Chemists.

[18]SPSS Inc. (2011) IBM SPSS Software for Windows, 20.0, Chicago.

[19]Snedecor G.W. and Cochran W.G (1987) Statistical Methods, Oxford IBH Publishing Co. Ltd., New Delhi.

[20]Sergius M., Beber M. and Rabkin I. (1926) The Journal of Biological Chemistry, 68, 547-563.

[21]Obeta J.A.N. (1983) Journal of Applied Bacteriology, 54, 433433.

[22]Isu N.R. and Njoku H.O. (1997) Plant foods for human nutrition, 51(2), 145-157.

[23]Enujiugha V.N. (2009) Pakistan Journal of Nutrition, 8, 279-283.

[24]Nwagu T.N., Amadi C. and Alakwe O. (2010) Pakistan Journal of Biological Sciences, 13, 497-503.

[25]Odunfa S.A. (1985) African Fermented Food in: Microbiology of Fermented Foods, 2, 155-195.

[26]Odunfa S.A. and Oyeyiola G.F. (1985) Journal of Plant foods, 6 (3), 155-163.

[27]Ogueke C.C. and Aririatu I.E. (2004) Nigerian Food Journal, 22 (1), 133-140.

[28]Mensah P., Owusu-Darko K., Yeboah-Manu D., Ablordey A., Nkrumah F. K. and Kamiya H. (1999) Ghana Medical Journal, 33, 19-29.

[29]Oranusi S., Galadima M., Umoh V.J. and Nwanze P.I. (2007) Scientific Research and Essay, 2(10), 426-433.

[30]Sweeney M. and Dobson A. (1998) International Journal of Food Microbiology, 43, 141-158.

[31]Kabak B., Dobson A. and Var I. (2006) Critical Reviews in Food Science and Nutrition, 46, 593-619.

[32] Oranusi S., Wesley B. and Oguoma O.I. (2013) Global Advanced Research Journal of Food Science and Technology, 2
(1), 01-06.

[33]Lamsal B.P. and Faubion J.M. (2009) Food Review International, 25, 103-114.

[34]Heenan C.N., Adams M.C., Hosken R.W. and Fleet G.H. (2004) Food Science and Technology, 37, 461-466.

[35]Cardarelli H.R., Aragon-Alegro L.C., Alegro J.H., de Castro I.A. and Saad S.M. (2008) Journal of the Science of Food and Agriculture, 88(8), 1318-1324.

[36]Possemiers S., Marzorati M., Verstraete W. and Wiele T.V. (2010) International Journal of Food Microbiology, 141, 97-103.

[37]Irkin R. and Guldas M. (2011) Acta agriculturae Slovenica, 97 (3), 223-232.

[38]Cruz A.G., Antunes A.E., Sousa A.L.O., Faria J.A. and Saad S.M. (2009) Food Research International, 42(9), 1233-1239.

[39]Ranadheera R.D.C.S., Baines S.K. and Adams M.C. (2010) Food Research International, 43, 1-7.

[40]Majchrzak D., Lahm B. and Dürrschmid K. (2010) Journal of Sensory Studies, 25, 431-446.

[41] International Commission on Microbiological Specifications for Foods (1996) Microorganisms in Foods 5: Microbiological Specifications of Pathogens.

[42]Mbata T. and Orji M.U. (2008) The Internet Journal of Microbiology, 4, 2-7. 